Research Article

\title{
The Effectiveness of Minimally Invasive Techniques in the Treatment of Patellar Tendinopathy: A Systematic Review and Meta-Analysis of Randomized Controlled Trials
}

\author{
M. P. López-Royo, ${ }^{1,2}$ M. Ortiz-Lucas $\mathbb{D}^{1},{ }^{1}$ E. M. Gómez-Trullén, ${ }^{2}$ and P. Herrero ${ }^{1}$ \\ ${ }^{1}$ Physio Reaserch Group, Universidad San Jorge, Campus Universitario, Autov. A23, Km 299, Villanueva de Gállego, \\ Zaragoza 50830, Spain \\ ${ }^{2}$ Universidad de Zaragoza, Facultad de Ciencias de la Salud, Dpto. de Fisiatría y Enfermería, C/Domingo Miral s/n, \\ Zaragoza 50009, Spain
}

Correspondence should be addressed to M. Ortiz-Lucas; mariaortizlucas@gmail.com

Received 8 June 2020; Revised 14 August 2020; Accepted 25 August 2020; Published 7 September 2020

Academic Editor: Blanca De la Cruz

Copyright (c) 2020 M. P. López-Royo et al. This is an open access article distributed under the Creative Commons Attribution License, which permits unrestricted use, distribution, and reproduction in any medium, provided the original work is properly cited.

\begin{abstract}
The aim was to determine the effectiveness of minimally invasive techniques (MIT) in patients with patellar tendinopathy. Database searches were performed for randomized controlled trials (RCTs) in electronic databases (WOS, Cochrane Central, SportDiscus, and Medline via PubMed and PEDro). The inclusion criteria used were published in English or Spanish and involving adults with patellar tendinopathy (pain on the inferior pole of the patella for a minimum of 3 months), with at least one group receiving MIT. The quality of the relevant RCTs was evaluated using the PEDro scale. The primary outcome was functionality using the VISA-p questionnaire. Secondary outcome was focused on pain. A total of 1164 studies were screened for possible inclusion in our systematic review. Finally, 10 RCTs were included with a total of 326 individuals. Five RCTs were included in the meta-analysis. The quality assessment revealed that all the studies included were considered to possess high methodological quality. All studies analyzing MIT such as platelet-rich plasma (PRP), dry needling, or skin-derived tenocyte-like cells, when combined with exercise, proved to be effective for patellar tendinopathy. Moreover, the PRP technique with doses greater than $4 \mathrm{~mL}$ together and combined with an exercise program lasting over 6 weeks obtained better results in functionality and pain than other treatments in the short term. However, in the long term, dry needling and skin-derived tenocyte-like cells are more effective than PRP. Although the infiltration of drugs was effective at posttreatment, these improvements were not maintained over time and may have secondary effects. Although there are no RCTs analyzing the effectiveness of MIT like percutaneous needle electrolysis, there has been an increasing number of publications achieving excellent results in the last years. However, it is necessary to develop RCTs analyzing not only the effect but also comparing the effectiveness between different MIT such as dry needling and percutaneous needle electrolysis.
\end{abstract}

\section{Introduction}

Patellar tendinopathy (PT) is a degenerative disease of the patellar tendon, in which the patient complains of pain in the inferior pole of the patella. Also, a disturbed collagen distribution, changes in vascularity and cellularity, increased thickness of tendon, and incompletely healed tendon microruptures are common changes observed in patients with this pathology [1-3]. The major cause of this injury is overuse during activities that involve jumping, running, and rapid changes of direction, which are very common movements in sports such a basketball and volleyball. Specifically, in nonprofessional athletes, the prevalence varies between $2.5 \%$ in soccer players and $14.4 \%$ in volleyball players. In contrast, in both elite sports, $40-50 \%$ of professional athletes are affected [4-6]. The diagnosis of PT is typically based on medical history and clinical findings [7]. Imaging techniques such as Color Doppler sonography (CD) and magnetic resonance 
imaging (MRI) are valuable tools to confirm the diagnosis and provide guidance for treatment [8].

Conventional treatments such as eccentric exercise (EE) programs for the quadriceps tendon, as a part of standard treatment, has demonstrated to have positive results, to the point that many authors have defended this technique as the gold standard for the treatment of tendinopathies [9-12]. A recent systematic review reported that the best exercise for improving knee function and reducing pain in the long term is based on EE and heavy slow resistance exercises (HSR) [13]. In addition, recent research has focused on minimally invasive techniques (MIT) using needles, with high expectations of success. These techniques seek a rapid regeneration of the injured tendon and the relief of chronic pain $[4,8,14-16]$. Their effect is based on stimulating the cellular activity and the production of collagen, as well as influencing the biomechanics of tendons to obtain restructuration of the matrix.

It can be classified according to whether they inject any substances or not. Regarding techniques that do not infiltrate any substances, good clinical results are being reported with dry needling (DN) [17] and percutaneous needle electrolysis (PNE) [4, 18-20], which adds the effect of the galvanic current to the mechanical effect of the needle. PNE combined with EE programs offer excellent results in terms of the clinical and functional improvement of the patellar tendon in the short-term and a rapid return to the previous level of activity $[4,18]$. Concerning techniques based on the infiltration of substances, it is possible to differentiate between pharmacological or nonpharmacological agents. The most used technique is platelet-rich plasma (PRP) [21-23]. Literature reviews carried out based on the application of the PRP technique on other tendons have concluded that there are no significant differences between PRP and DN or placebo at the 6-months follow-up, although it seems that there may be small differences depending on the injured tendon [24]. Moreover, some reviews and meta-analysis have analyzed the effect of PRP in PT versus other techniques, regardless of whether they are conservative or invasive treatments, finding that PRP seems to be a more effective treatment in the long term than other treatments, such as extracorporeal shockwave therapy (ESWT) $[15,25,26]$. However, when compared to other invasive treatments such as cell therapy or DN, the results for PRP are worse regarding functionality in the long term, whereas these other techniques have a promising future for this pathology $[27,28]$. Most studies conclude that more studies, specifically for randomized controlled trials (RCTs), are necessary to make accurate conclusions with scientific rigor, as most of the included studies reviewed are of low scientific quality.

A variety of MIT are being used in clinics for the treatment of PT, either used alone or as a complement to other conservative treatments. However, evidence-based therapies are limited, and there is no consensus regarding which of these is the most effective. The variability of the types of studies, together with the low quality of the same, lead us to consider the need for a review and meta- analysis of high-quality RCT on MIT for the treatment of PT.

Thus, our primary aim was to systematically review the effectiveness of MIT for functionality and pain of the PT in humans. Where possible, meta-analysis of outcome data on pain and function was performed.

\section{Materials and Methods}

A systematic review and meta-analysis were performed according to the Preferred Reporting Items for Systematic Review and Meta-Analysis (PRISMA) [29]. The review was registered in the international PROSPERO database (CRD42015025801). The software used to assemble all the papers included in this review is EndNote X7 v17.0.1.

2.1. Data Sources and Searches. We conducted a systematic literature search in Web of Science, Cochrane Central, SportDiscus, and Medline via PubMed and PEDro. The database search was conducted by two reviewers (MPLR and EMGT) in January 2018 with the final search conducted in September 2019, using the following search terms: patellar ten $*$, patellar ligament, jumper's knee, chronic patellar ten*, dry need $*$, intratissue percutaneous electrolysis, acupuncture, electroacupuncture, mesotherapy, injection, injectable*, puncture, and infiltrate*. Search strategy for Medline is described in detail in Appendix 1.

Two independent reviewers (MPLR and EMGT) screened the titles and/or abstracts and full texts according to the stated inclusion criteria. Discrepancies were discussed at a consensus meeting, and the opinion of a third independent reviewer (MOL) was sought if agreement could not be achieved. Reviewers were not blinded to information regarding the authors, journal of origin, or outcomes for each paper reviewed.

2.2. Study Selection. The inclusion criteria were as follows: (a) RCT; (b) English or Spanish; (c) involving adults; (d) with a diagnosis of chronic patellar disease (minimum of 3 months of pain in the inferior pole of the patella); and (e) at least one group receiving MIT. We excluded articles in which the sample was under 18 years old, non-RCTs (quasiexperimental trials, case series, and observational studies), and those in which subjects had received a previous surgical intervention.

In studies with more treatment groups in which patients underwent different procedures, each treatment group was analyzed independently according to the treatment applied and always compared with the group receiving MIT.

2.3. Data Extraction. The primary outcome evaluated was functionality using the Victorian Institute of Sport Assessment of Patellar Questionnaire (VISA-p) [30]. Secondary outcome measures focused on pain.

A standardized electronic data extraction form was developed to obtain key information relevant to this review. Data extraction for each article was performed by two 
authors (MPLR and EMGT), with a third reviewer (MOL) solving potential discrepancies, and including the following: (1) sample characteristics (sample age and sample sex); (2) methodological characteristics (study design, number of groups, associated interventions, time of measurements, and assessment tools); (3) main results; and (4) conclusions.

Finally, a meta-analysis was performed grouping the RCTs according to the technique used. Means, standard deviation (SD), and sample sizes for pain and function were extracted for each group at short-term and medium/long-term followup. When data were not extractable or expressed in other form instead of mean and SD, a total of three attempts were made contacting with the corresponding author to request the information by e-mail, and in case of not getting an answer of the study data, were not used for the meta-analysis. To analyze the benefit of this treatment, studies without pre- and postintervention data were excluded.

2.4. Risk of Bias Assessment. The quality of the relevant RCTs was evaluated using the PEDro scale. Eleven PEDro criteria were used to evaluate the quality of the retrieved studies. Each satisfied item (except for item 1, which, unlike other scale items, pertains to external validity) contributes one point to the total PEDro score (range $0-10$ points). Each criterion was assessed with the alternatives "Yes" (1 point) or "No" (0 points). Items 2-9 assess internal validity, and the last two items (10 and 11) reveal whether the statistical information presented in the study is enough to perform a correct interpretation of the outcomes. Articles fulfilling at least 6/10 positive criteria were considered to be of "good quality," studies with 4-5/10 positive criteria were considered to be "average quality," and articles with less than 4 points were considered "poor quality" [31]. Two reviewers (MPLR and EMGT) separately evaluated the quality of the studies using the PEDro scale, and when they could not reach agreement, a third independent reviewer was consulted.

2.5. Statistical Analysis. The random effects model was used for all meta-analyses. The VISA-p score and visual analog scale (VAS) mean differences and SD for each group (between pre and posttreatment and between pretreatment and the follow up) were collected for this purpose. Heterogeneity between studies was assessed using the Cochran's Q test, and the $\mathrm{I}^{2}$ index was used to quantify the amount of heterogeneity, with a value greater than $50 \%$ indicating substantial heterogeneity $[32,33]$. Additional intragroup meta-analyses of each treatment differences of means were performed to explain the heterogeneity found. Also, subgroup analyses were performed according to dose ( $\leq$ or $>4 \mathrm{~mL}$ ), amount of exercise ( $\leq$ or $>6$ weeks), and basal VISA-p score $(<$ or $\geq 48)$. Prior to this, scatter plots of possible factors of heterogeneity were drawn to detect suitable variables for subgroup analyses and their cut off values.

\section{Results}

3.1. Characteristics of Included Trials. A total of 1164 studies were screened for possible inclusion in this systematic review; 10 RCTs met our inclusion criteria and included in the review (Figure 1).

All the articles included in the present review involved 326 individuals, most of whom were athletes practicing various sports and aged between 18 and 55 years. Functionality with VISA-p was assessed in eight studies $[8,21,23,34-38]$, and pain was evaluated using a numeric scale in all studies except one [38]. The main features of these studies are summarized in Table 1 . The quality assessment revealed that all the studies included were considered to be of high methodological quality ( $\geq 6$ points about 10) (Appendix 2).

\section{Review}

A heterogeneity of results was found after performing the systematic review. On the one hand, MIT that do not infiltrate any substances such as DN or PNE showed a high increase of studies in the last years, although the studies published are still of low quality except for the one published by Dragoo et al. [21]. However, there was a protocol published by Lopez-Royo et al [41] analyzing the additional effects of both DN and PNE over EE whose results have not published yet, but that will increase the knowledge in this field. On the other hand, other therapies including the infiltration of substances, such as PRP therapy, were associated with a significant improvement in functionality and pain at posttreatment [21, 34-37] and at follow-up measurements [21, 35-37] and a significant decrease in hypoechogenicity and tear size at 6 months [37] in patients with PT, with no significant differences between one or two PRP injections.

In the systematic review, we found studies comparing different interventions, such as a study that compared PRP with ESWT, showing that the effectiveness of two injections of PRP was superior for pain and functionality measurements at posttreatment and at follow-up and for pain only at follow-up [35]. In other study, that compared PRP with DN therapy, controversial results were observed, as, in the short term (3 months), PRP obtained better results on pain and functionality compared to DN, whereas at 6 months, $\mathrm{DN}$ was more effective than PRP for functionality [21]. In this study, when comparing subjects at baseline, DN was more effective than PRP on levels of pain and function also at 6 months. Moreover, other RCTs have reported PRP as being less effective than other therapies [34,37], like the study comparing PRP with tenocyte-like cell treatment at 6 months [37], with the latter showing improved effectiveness for functionality, pain, tendon thickness, hypoechogenicity, and tear size. In other recent study [34], comparing two different groups of leukocyte-poor PRP (LP-PRP) and leucocyte-rich PRP (LR-PRP) versus saline injection, $58 \%$ of the patients experienced an improvement of the VISA-p score at posttreatment regardless of their assigned treatment group. In this study, no significant differences were found between the three groups in the short term, failing to demonstrate any significant benefit of LP-PRP or LR-PRP over saline injection. Eventually, the effectiveness of the autologous blood $(\mathrm{AB})$ injections was studied in a recent RCT [38], showing that both $\mathrm{AB}$ and saline groups experienced a significant 


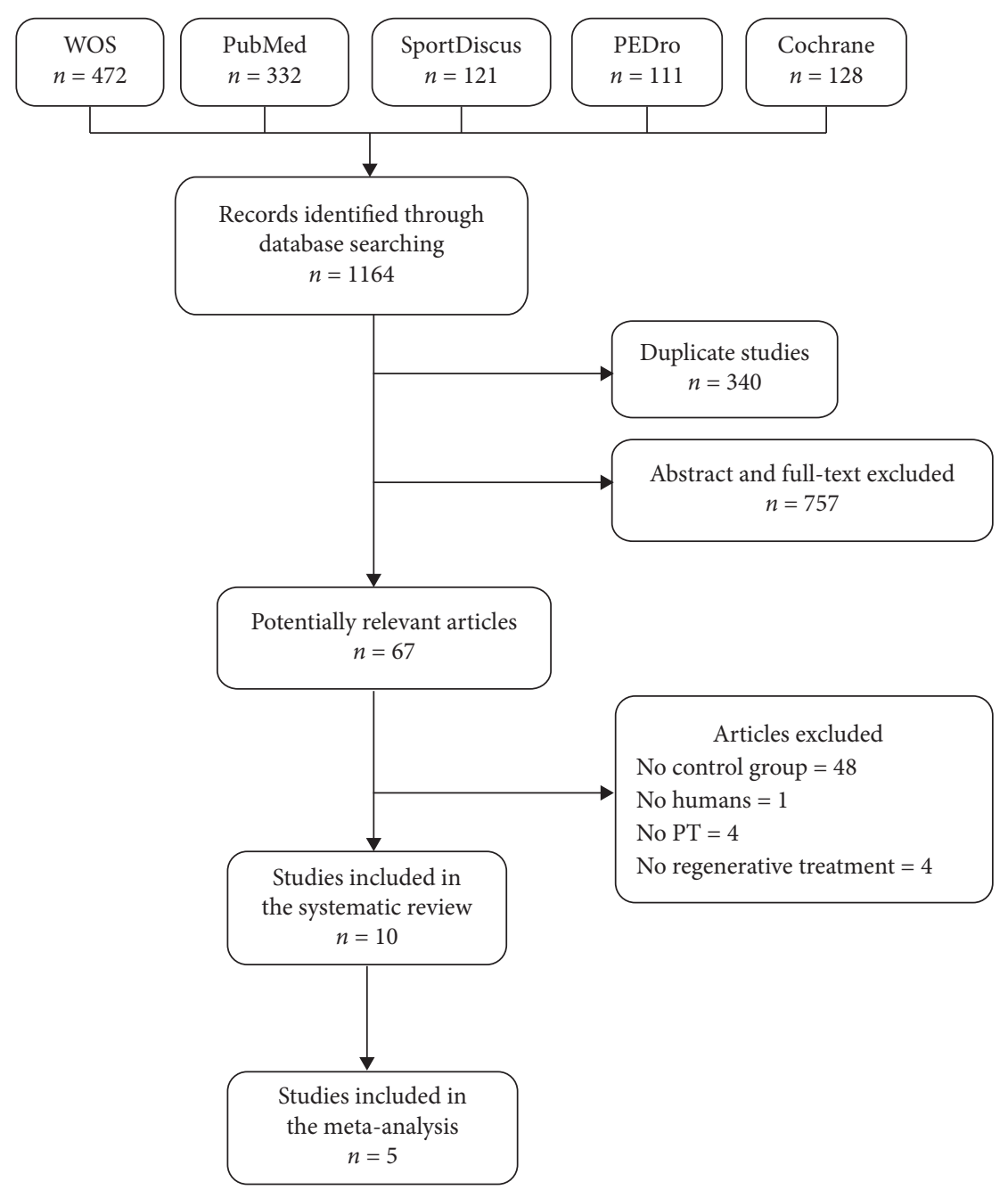

FIgURe 1: PRISMA flow diagram. PT=patellar tendinopathy; WOS=Web of Science.

improvement in symptoms, with nonsignificant statistical differences between groups.

Regarding pharmacological treatments, several studies $[8,23,38-40]$ applied different drug infiltrations protocols, including steroids and sclerosing agents. A study comparing steroids with placebo showed an improvement at 6 months in the steroids group for pain measured with a numeric rating scale and a decrease of tendon thickness, maintaining this effect at 6 months [39]. Nevertheless, in a study comparing corticosteroid injections (CI) with EE and HSRT, all groups improved functionality, pain, and tendon thickness and swelling, with significant differences in favor of the CI group when compared with the other two exercise groups in the short term. However, these improvements were maintained at 6 months for both exercise groups but not for the group receiving corticosteroids [23]. Polidocanol was effective on functionality at 4 months posttreatment in one study [8]; however, no results were found in VAS measurements either in the short or long term [8, 40]. Furthermore, functional improvements were not maintained at long-term [8]. In a subsequent study of the same group with a 44-months follow-up, more than one-third of the group treated with polidocanol ended up in a surgical intervention because of the pain they suffered. Willberg et al. [40] in their study showed that the group receiving arthroscopic treatment found better improvements in pain and satisfaction compared to baseline as opposed to the cited polidocanol group at 6 weeks [40]; however, once again, the results were lost in the follow-up period (2, 6, and 12 months).

4.1. Meta-Analysis. The only MIT with enough RCTs to carry out a meta-analysis was PRP. For this reason, we included all articles with at least one group consisting of PRP injection treatment. Finally, five RCTs were included in the meta-analysis (Figure 1).

For the meta-analysis, different cutoff points were established. Regarding the dose of treatment received, three RCTs [21, 36, 37] applied doses equal to or greater than $4 \mathrm{~mL}$ of PRP, and two RCTs [34,35] employed three different injections, applying doses less than $4 \mathrm{~mL}$. These same subgroups were obtained when comparing the duration of EE performed by the subjects of the PRP group. When the dose was bigger than $4 \mathrm{~mL}$ of PRP, a program of over 6 weeks of exercise was continued; 
TABLE 1: Study characteristics of the included trials.

\begin{tabular}{|c|c|c|c|c|c|}
\hline Study (y) & $\begin{array}{l}\text { Participants } \\
(N \text {, age, sex })\end{array}$ & Intervention & Outcomes & Results & Conclusion \\
\hline $\begin{array}{l}\text { Dragoo et al. } \\
(2014)[21]\end{array}$ & $\begin{array}{c}\mathrm{DN}(n=12, \\
40(\mathrm{SD} 14) \\
\mathrm{yrs}, 100 \% \mathrm{M})\end{array}$ & $\begin{array}{c}\text { A nurse obtained } 55 \mathrm{~mL} \text { of } \\
\text { peripheral blood that was } \\
\text { discarded. } \\
3 \mathrm{~mL} \text { of } 0.25 \% \text { bupivacaine } \\
\text { with } 1: 100,000 \\
\text { epinephrine were then } \\
\text { injected subcutaneously } \\
\text { using a sterile technique to } \\
\text { anesthetize. Subsequently, } \\
10 \text { mechanical needle } \\
\text { insertions were performed } \\
\text { in the area of the } \\
\text { tendinopathy. } \\
\text { Standardized a } 5 \text {-phase } \\
\text { program of EE during } \\
12 \text { wks. } \\
\text { A nurse obtained } 55 \text { mL of } \\
\text { peripheral blood, and it was } \\
\text { processed. Then, } 3 \text { mL of } \\
\text { 0.25\% bupivacaine with } 1: \\
\text { 100,000 epinephrine was } \\
\text { subcutaneously injected } \\
\text { using a sterile technique to } \\
\text { anesthetize. This was } \\
\text { followed by } 6 \text { mL } \\
\text { infiltration of leukocyte- } \\
\text { rich PRP. Finally, } 10 \\
\text { mechanical needle } \\
\text { insertions were performed } \\
\text { in the area of the } \\
\text { tendinopathy. Standardized } \\
\text { a } 5 \text {-phase program of EE } \\
\text { during } 12 \text { wks. }\end{array}$ & $\begin{array}{l}\text { Functionality: VISA- } \\
\text { p, Tegner/Lysholm. } \\
\text { Pain: VAS. } \\
\text { Others: SF-12. } \\
\text { Temporality: pre/post } \\
\text { (12 wks)/follow-up } \\
\text { (26 wks). }\end{array}$ & $\begin{array}{c}\text { DN: significant } \\
\text { improvement from } \\
\text { baseline on Lysholm at } \\
12 \text { wks and on VISA-p, } \\
\text { Tegner, Lysholm, and } \\
\text { VAS at } 26 \text { wks. } \\
\text { PRP: significant } \\
\text { improvement from } \\
\text { baseline on VISA-p, } \\
\text { Lysholm, and VAS at } \\
12 \text { wks and on VISA-p } \\
\text { and VAS at } 26 \text { wks. } \\
\text { DN vs. PRP: significant } \\
\text { improvement in PRP vs. } \\
\text { DN on VISA-p at } \\
12 \text { wks and DN vs. PRP } \\
\text { on Lysholm at } 26 \text { wks. }\end{array}$ & $\begin{array}{l}\text { The PRP group showed a } \\
\text { significant improvement } \\
\text { compared with the DN } \\
\text { group at } 12 \text { wks, but the } \\
\text { difference between groups } \\
\text { was not significant at } \\
26 \text { wks. } \\
\text { Lysholm scores were not } \\
\text { significantly different } \\
\text { between groups at } 12 \text { wks, } \\
\text { but the DN group had } \\
\text { improved significantly } \\
\text { more than the PRP group } \\
\text { at } 26 \text { wks. }\end{array}$ \\
\hline $\begin{array}{l}\text { Clarke et al. } \\
(2010) \text { [37] }\end{array}$ & $\begin{array}{l}\text { Cells }(n=33) \\
\text { total sample: } \\
36 \text { yrs }(20-51)\end{array}$ & $\begin{array}{l}\text { Skin-biopsy: } 4 \text {-mm skin } \\
\text { sample. } 1 \text { infiltration of } \\
\text { isolated and amplified } \\
\text { cells + plasma. } \\
\text { Standardized program of } \\
\text { increased eccentric loading } \\
\text { and stretching exercises } \\
\text { during } 6 \text { mo. } \\
\text { Skin biopsy: } 4 \text {-mm skin } \\
\text { sample. } 1 \text { infiltration of } \\
\text { centrifuged autologous } \\
\text { whole blood ( } 8 \text { mL). } \\
\text { Standardized program of } \\
\text { increased eccentric loading } \\
\text { and stretching exercises } \\
\text { during } 6 \text { mo. }\end{array}$ & $\begin{array}{c}\text { Functionality: VISA- } \\
\text { p. } \\
\text { Others: US (tendon } \\
\text { thickness, } \\
\text { hypoechogenicity, } \\
\text { intrasubstance tears, } \\
\text { and neovascularity). } \\
\text { Temporality: pre/post } \\
\text { (6 wks)/follow-up } \\
\text { (3 mo and } 6 \text { mo). }\end{array}$ & $\begin{array}{l}\text { Cells: significant } \\
\text { improvement from } \\
\text { baseline on VISA-p, } \\
\text { tendon thickness, } \\
\text { hypoechogenicity and } \\
\text { tear size at } 6 \text { mo. } \\
\text { PRP: significant } \\
\text { improvement from } \\
\text { baseline on VISA-p, } \\
\text { hypoechogenicity, and } \\
\text { tear size at } 6 \text { mo. } \\
\text { Cells vs. PRP: } \\
\text { significant } \\
\text { improvement in cells vs. } \\
\text { PRP on VISA-p at } 6 \text { mo. }\end{array}$ & $\begin{array}{l}\text { Ultrasound-guided } \\
\text { injection of autologous } \\
\text { skin-derived tendon-like } \\
\text { cells can be safely used at } \\
6 \text { mo to treat PT, with a } \\
\text { faster treatment response } \\
\text { and significantly greater } \\
\text { improvements in pain and } \\
\text { function than with plasma } \\
\text { alone. }\end{array}$ \\
\hline
\end{tabular}


TABle 1: Continued.

\begin{tabular}{|c|c|c|c|c|c|}
\hline Study (y) & $\begin{array}{l}\text { Participants } \\
(N, \text { age, sex })\end{array}$ & Intervention & Outcomes & Results & Conclusion \\
\hline $\begin{array}{l}\text { Kongsgaard } \\
\text { M. et al. } \\
(2009)[23]\end{array}$ & $\begin{array}{c}\text { CORT } \\
(n=13,34.3 \\
(\mathrm{SD} 10.0) \mathrm{yrs}) \\
\\
\mathrm{EE}(n=13, \\
31.3 \text { (SD 8.3) } \\
\text { yrs) }\end{array}$ & $\begin{array}{l}\text { Injections of } 1 \mathrm{~mL} \text { of } 40 \mathrm{mg} / \\
\mathrm{mL} \text { methylprednisolone in } \\
0.5 \mathrm{~mL} \text { lidocaine }(1 \%) \text {. } \\
\text { Second injection was } 4 \mathrm{wks} \\
\text { later. } \\
3 \times 15 \text { repetitions of } \\
\text { eccentric unilateral squats } \\
\text { on a } 25^{\circ} \text { decline board twice } \\
\text { daily for } 12 \text { wks. }\end{array}$ & $\begin{array}{l}\text { Functionality: VISA- } \\
\text { p. } \\
\text { Pain: VAS. } \\
\text { Others: US (tendon } \\
\text { swelling) and CD } \\
\text { (vascularization). } \\
\text { Temporality: pre/post } \\
\text { (12 wks) /follow-up } \\
\text { (6 mo). }\end{array}$ & $\begin{array}{l}\text { CORT: significant } \\
\text { improvement from } \\
\text { baseline on VISA-p, } \\
\text { VAS, tendon thickness, } \\
\text { and color area at } 12 \text { wks. } \\
\text { ECC: significant } \\
\text { improvement on VISA- } \\
\text { p and VAS at } 12 \text { wks } \\
\text { and } 6 \text { mo. } \\
\text { HSRT: significant } \\
\text { improvement on VISA- } \\
\text { p, VAS, tendon } \\
\text { thickness, and color } \\
\text { area at } 12 \text { wks and on } \\
\text { VISA-p and VAS at } \\
6 \text { mo. } \\
\text { HSRT vs. EE vs. CORT: } \\
\text { VISA-p improvement } \\
\text { from baseline to } 6 \text { mo } \\
\text { was significantly higher } \\
\text { in HSRT and EE than } \\
\text { CORT. } \\
\text { VAS improvement } \\
\text { from baseline to } 6 \text { mo } \\
\text { was significantly greater } \\
\text { in HSRT compared with } \\
\text { CORT. }\end{array}$ & $\begin{array}{l}\text { CORT has good clinical } \\
\text { effects at } 3 \text { mo but poor } \\
\text { results at } 6 \text { mo in PT. } \\
\text { HSRT and EE have good } \\
\text { clinical effects at } 3 \text { and } \\
6 \text { mo accompanied by an } \\
\text { improvement in the } \\
\text { pathology. }\end{array}$ \\
\hline
\end{tabular}

First treatment: polidocanol $10 \mathrm{mg} / \mathrm{mL} 3$

TG $(n=17$,

$25.4(\mathrm{SD} 7.5)$

yrs)

Hoksrud et

al. (2006) [8]

CG $(n=16$,

24.3 (SD 4.5)

yrs)

times maximum in $4 \mathrm{mo}$.

Second treatment (at $4 \mathrm{mo}$ ): maximum 3 sclerosing polidocanol injections conditioned to patient willingness.

First treatment: lidocaine with adrenaline (xylocaineadrenalin) $(5 \mathrm{mg} / \mathrm{mL}+5 \mathrm{~g} /$ $\mathrm{mL}$ ). Second treatment (at 4 mo): maximum 3 sclerosing polidocanol injections conditioned to the patients' willingness.

3 infiltrations $(0,7$, and 21

Steroids days). Steroid injection

$(n=12)$; total (contained $3.5 \mathrm{~mL}$ of

sample: $\quad 10 \mathrm{mg} / \mathrm{mL}$ lidocaine and

$28.4 \mathrm{yrs} \quad 0.5 \mathrm{~mL}$ Kenalog containing

Fredberg et $\quad(18-47)$

al. (2004)

[39]

Placebo $(n=12)$; total

sample:

$28.4 \mathrm{yrs}$

(18-47)
$20 \mathrm{mg}$ triamchinolone in a 5-mL syringe).

3 infiltrations $(0,7$, and 21 days). Placebo injection contained $3.5 \mathrm{~mL}$ of $1 \%$ lidocaine and $0.5 \mathrm{~mL}$ of $20 \%$ intralipid in a $5-\mathrm{mL}$ syringe
Functionality: VISAp.

Pain: VAS during squat testing.

Satisfaction: $100-\mathrm{mm}$ long scale.

Temporality: pre/post

(4 mo)/follow-up (8 and $12 \mathrm{mo}$ ).

Pain: NRS, algometry.

Others: US (tendon thickness).

Temporality: pre (7

days)/post (21 days)/

follow-up (28 days and $6 \mathrm{mo}$ ).
TG: significant improvement on VISA$p$ at 4 mo.

CG: significant improvement on VISA$\mathrm{p}$ at 8 and $12 \mathrm{mo}$.

TG vs. CG: more satisfaction in TG compared with the CG at $4 \mathrm{mo}$.
Sclerosing injections with polidocanol resulted in a significant improvement in knee function and reduced pain measured with VISA-p in patients with PT.
Steroids: significant improvement from baseline on tendon diameter at 7 days, 21 days, and 6 mo and on pressure-pain at 21 days.

Steroids vs. Placebo: significant improvement in steroids vs. placebo on NRS at $6 \mathrm{mo}$.
Ultrasonographically guided injection of longacting steroid can normalize the ultrasonographic pathological lesions in the PT. 
TABle 1: Continued.

\begin{tabular}{|c|c|c|c|c|c|}
\hline Study (y) & $\begin{array}{l}\text { Participants } \\
(N, \text { age, sex })\end{array}$ & Intervention & Outcomes & Results & Conclusion \\
\hline $\begin{array}{l}\text { Vetrano et al. } \\
(2013) \text { [35] }\end{array}$ & $\begin{array}{c}\text { ESWT } \\
(n=23,26.8 \\
(\text { SD } 8.5) \text { yrs, } \\
73.9 \% \mathrm{M})\end{array}$ & $\begin{array}{l}10 \mathrm{~mL} \text { of venous blood was } \\
\text { collected. } 2 \text { autologous PRP } \\
\text { injections }(2 \mathrm{~mL}) \text { over } \\
2 \text { wks. } \\
\text { Standardized stretching } \\
\text { and muscle strengthening } \\
\text { protocol ( } 2 \text { wks). } \\
3 \text { sessions in } 48-72 \mathrm{~h} \\
\text { intervals. } 2.400 \text { impulses } \\
\text { with an energy flux density } \\
\text { of } 0.17-0.25 \mathrm{~mJ} / \mathrm{mm}^{2} \text {. } \\
\text { Standardized stretching } \\
\text { and muscle strengthening } \\
\text { protocol ( } 2 \text { wks). }\end{array}$ & $\begin{array}{c}\text { Functionality: VISA- } \\
\text { p. } \\
\text { Pain: VAS. } \\
\text { Temporality: pre/ } \\
\text { follow-up }(2,6 \text {, and } \\
12 \mathrm{mo}) \text {. }\end{array}$ & $\begin{array}{c}\text { PRP: significant } \\
\text { improvement from } \\
\text { baseline on VISA-p and } \\
\text { on VAS at 2,6, and } \\
12 \text { mo. } \\
\text { ESWT: significant } \\
\text { improvement from } \\
\text { baseline on VISA-p and } \\
\text { on VAS at 2,6, and } \\
12 \text { mo. } \\
\text { PRP vs. ESWT: } \\
\text { significant } \\
\text { improvement in PRP vs. } \\
\text { ESWT in VISA-p and } \\
\text { VAS at } 6 \text { and } 12 \text { mo. }\end{array}$ & $\begin{array}{l}\text { Therapeutic injections of } \\
\text { PRP lead to better clinical } \\
\text { results at } 6-12 \text { mo } \\
\text { compared with focused } \\
\text { ESWT in the treatment of } \\
\text { PT in athletes. }\end{array}$ \\
\hline $\begin{array}{l}\text { Kaux et al. } \\
\text { (2015) [36] }\end{array}$ & $\begin{array}{l}\text { PRP }(n=10 \\
31.1 \text { (SD 10, } \\
\text { 4) yrs) }\end{array}$ & $\begin{array}{c}2 \text { PRP injections }(6 \mathrm{~mL}) 1 \\
\text { one between } \\
\text { them }+ \text { standardized EE } \\
15 \times 3 \text { times } / 5 \text { times a week. }\end{array}$ & $\begin{array}{c}\text { Functionality: VISA- } \\
\text { p. } \\
\text { Pain: VAS and } \\
\text { algometer. } \\
\text { Others: isokinetic } \\
\text { (Cyber Norm), IKDC } \\
\text { and US. } \\
\text { Temporality: pre/ } \\
6 \text { wks/3 mo. }\end{array}$ & $\begin{array}{l}\text { 1 PRP: significant } \\
\text { improvement from } \\
\text { baseline in VAS, } \\
\text { pressure algometer, } \\
\text { IKDC, and VISA-p at } \\
3 \text { mo. } \\
\mathbf{2} \text { PRP: significant } \\
\text { improvement from } \\
\text { baseline in VAS, } \\
\text { pressure algometer, } \\
\text { IKDC, and VISA-p at } \\
3 \text { mo. } \\
\mathbf{1} \text { PRP vs. } 2 \text { PRP: } \\
\text { significant } \\
\text { improvement in } 1 \text { PRP } \\
\text { Vs. } 2 \text { PRP in pressure } \\
\text { algometer and IKDC at } \\
3 \text { mo. And an increase } \\
\text { of the sagittal } \\
\text { hypoechoic area. }\end{array}$ & $\begin{array}{l}\text { A local infiltration of PRP } \\
\text { associated with EE is } \\
\text { efficient to improve } \\
\text { symptoms of PT. The } \\
\text { application of } 1 \text { or } 2 \\
\text { infiltration of PRP did not } \\
\text { reveal any difference } \\
\text { between groups. }\end{array}$ \\
\hline $\begin{array}{l}\text { Willberg et } \\
\text { al. (2011) [40] }\end{array}$ & $\begin{array}{c}\text { Group } 1 \\
(n=26,27.0 \\
(\text { SD } 7.6) \text { yrs }) \\
\\
\text { Group } 2 \\
(n=26,26.6 \\
(\text { SD } 7.6) \text { yrs })\end{array}$ & $\begin{array}{l}\text { Sclerosing polidocanol } \\
\text { injections }(2 \mathrm{~mL}), \\
\text { maximum } 3 \text { times (at least } \\
6 \text { weeks in between). } \\
\text { Arthroscopic shaving was } \\
\text { performed under local } \\
\text { anesthesia. Standard } \\
\text { anteromedial and } \\
\text { anterolateral portals. }\end{array}$ & $\begin{array}{l}\text { Pain: VAS at rest and } \\
\text { during sport activity. } \\
\text { Satisfaction: } 100-\mathrm{mm} \\
\text { long scale. } \\
\text { Temporality: pre/post } \\
\text { (6 wks)/follow-up (2, } \\
\text { 6, and } 12 \text { mo). }\end{array}$ & $\begin{array}{c}\text { Group 2: significant } \\
\text { improvement from } \\
\text { baseline in VAS at rest } \\
\text { and with activity and in } \\
\text { satisfaction } \\
\text { posttreatment. }\end{array}$ & $\begin{array}{l}\text { Patients treated with } \\
\text { arthroscopic shaving had } \\
\text { less pain and were more } \\
\text { satisfied with the treatment } \\
\text { result. }\end{array}$ \\
\hline $\begin{array}{l}\text { Resteghini et } \\
\text { al. (2016) [38] }\end{array}$ & $\begin{array}{c}\text { Saline }(n=11 \\
39 \mathrm{yrs})\end{array}$ & $\begin{array}{c}2 \mathrm{~mL} \text { of } \mathrm{AB} \text { was extracted. } \\
2 \mathrm{~mL} \mathrm{AB} \text { injection }+\mathrm{EE} \\
3 \text { mo }\end{array}$ & $\begin{array}{c}\text { Functionality: VISA- } \\
\text { p. } \\
\text { Pain: SF-MPQ and } \\
\text { VA. } \\
\text { Temporality: pre/post } \\
\text { (6 wks)/follow-up ( } 3 \\
\text { 6, and } 12 \text { mo) }\end{array}$ & $\begin{array}{c}\text { AB: significant } \\
\text { improvement VAS, } \\
\text { VISA-p, SF-MPQ at } \\
1 \text { mo/3 mo/1 yr. } \\
\text { Saline group: significant } \\
\text { improvement VAS, } \\
\text { VISA-p, and SF-MPQ at } \\
1 \text { mo/3 mo/ } 1 \text { yr. } \\
\text { AB vs. saline: no } \\
\text { significant differences. }\end{array}$ & $\begin{array}{l}\mathrm{AB} \text { and saline groups } \\
\text { experienced a significant } \\
\text { improvement in } \\
\text { symptoms. However, } \\
\text { when the results were } \\
\text { compared, there was no } \\
\text { statistical difference } \\
\text { between the } 2 \text { groups. }\end{array}$ \\
\hline
\end{tabular}


TABLE 1: Continued.

\begin{tabular}{|c|c|c|c|c|c|}
\hline Study (y) & $\begin{array}{l}\text { Participants } \\
(N \text {, age, sex })\end{array}$ & Intervention & Outcomes & Results & Conclusion \\
\hline $\begin{array}{l}\text { Scott et al. } \\
\text { (2019) [34] }\end{array}$ & 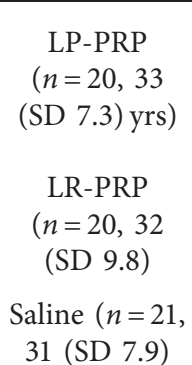 & $\begin{array}{l}52 \mathrm{~mL} \text { of venous blood was } \\
\text { collected. } 2 \% \text { hematocrit in } \\
3.5 \mathrm{~mL} \text { PRP + HSRT } 3 \\
\text { times/wk during } 6 \text { wks. } \\
52 \mathrm{~mL} \text { of venous blood was } \\
\text { collected. } 15 \% \text { haematocrit } \\
\text { in } 3.5 \mathrm{~mL} \text { PRP + HSRT } 3 \\
\text { times/wk during } 6 \text { wks. } \\
3.5 \mathrm{~mL} \text { saline + HSRT } 3 \\
\text { times/wk during } 6 \text { wks. }\end{array}$ & $\begin{array}{c}\text { Functionality: VISA- } \\
\text { p. } \\
\text { Pain: NRS. } \\
\text { Temporality: pre/post } \\
(6 \text { wks)/follow-up ( } 3 \text {, } \\
\text { 6, and } 12 \mathrm{mo})\end{array}$ & $\begin{array}{c}\text { No significant } \\
\text { difference between } \\
\text { groups in any time. }\end{array}$ & $\begin{array}{l}\text { Combined with an } \\
\text { exercise-based } \\
\text { rehabilitation program, a } \\
\text { single injection of LR-PRP } \\
\text { or LP-PRP was no more } \\
\text { effective than saline for the } \\
\text { improvement of PT } \\
\text { symptoms. }\end{array}$ \\
\hline
\end{tabular}

$\overline{\mathrm{AB}}$, autologous blood; Cells, prepared in laboratory (cells of collagen and plasma); CD, Color Doppler; CG, control group; CORT, peritendinous corticosteroid injections; DN, dry needling; EE, eccentric decline squat training; ESWT, extracorporeal shock wave therapy; HSRT, heavy slow resistance training; IKDC, international knee documentation committee form; LP-PRP, leukocyte poor PRP; LR-PRP, leukocyte rich PRP; M, masculine; mo, months; MRI, magnetic resonance imaging; $N$, number; NRS, numeric rating scale; PRP, platelet-rich plasma; PT, patellar tendinopathy; RCT, randomized control trial; SF12, Short Form-12; TG, treatment group; US, ultrasound; VAS, visual analog scale; VISA-p, Victorian Institute of Sport Assessment of Patellar; wks, weeks; yr, years.

however, when the dose was less than $4 \mathrm{~mL}$, the exercise program lasted 6 weeks or less. Regarding the mean baseline score of the VISA-p, the following subgroups were defined: subjects with less than 48 points [21, 34] and subjects with more than 48 points [34-37].

4.2. Intergroup Differences. There was no difference between groups in the case of the VISA-p after treatment or at follow-up (Figures 2(a) and 2(b)). However, in those studies where the dose was greater than $4 \mathrm{~mL}$ and the duration of the exercise program was longer than 6 weeks, treatment with PRP was better than other therapies after treatment. Surprisingly, the opposite happened in the follow-up (Figures 3(a) and 3(b)).

Concerning the effectiveness of treatment in the management of pain measured by VAS, PRP was superior to other treatments in the case of doses greater than $4 \mathrm{~mL}$ and exercise programs of more than 6 weeks duration after treatment. In the follow-up, there were no differences between groups in any of the situations (Figures 4(a) and $4(b))$.

4.3. Intragroup Differences for the PRP Group. Concerning the intragroup analysis of those patients treated with PRP, treatment was effective both after treatment and during the follow-up, according to both measurement scales: the VISA$\mathrm{p}$ (Figures 5(a) and 5(b)) and VAS (Figures 6(a) and 6(b)). In the case of pain, heterogeneous findings were found; however, the results of all studies suggest an improvement after treatment.

\section{Discussion}

The main finding of this study was that all studies analyzing MIT, such as PRP, DN, or cells, when combined with exercise, were found to be effective for PT at posttreatment and follow-up. This systematic review has identified ten RCTs assessing the effectiveness of MIT in the treatment of PT. A meta-analysis was conducted with five RCTs that included PRP injection. It was not possible to perform meta-analysis with other MIT due to a lack of data for conducting statistical analysis. All studies selected in this review had a high-quality level.

MIT can be divided into two different groups, depending on whether they inject any substances or not. For the injection of substances, a differentiation can be made between infiltrating pharmacological agents or nonpharmacological ones. In our review, all injection therapies with pharmacological agents (i.e., steroids, corticosteroids, and polidocanol) obtained good clinical effects in the short term, even for the decrease of the tendon diameter [8, 23, 40]; however, in the long term, results were poor [8]. These findings are in line with the conclusions of previous systematic reviews for the treatment of other tendon disorders affecting other areas of the body $[42,43]$. Furthermore, the role of steroids in the management of tendinopathy is also controversial, suggesting the relapse of symptoms in the long term [43]. Also, steroid injections may produce undesirable side effects, such as tendon rupture, as reported elsewhere [42, 44].

Concerning infiltration with nonpharmacological agents such as PRP, in this meta-analysis, as reported by several RCTs [25, 26, 42, 45], PRP was found to be an effective technique for PT treatment, and these effects were maintained in the long term. Nonetheless, these studies conclude the need to perform further quality RCTs including placebo treatments to elucidate their true effects. Moreover, this study has found that other MIT such as tenocyte-like cells or DN may have better results in the long term for this pathology. Studies focusing on other tendinopathies, which compare PRP versus MIT that do not infiltrate substances, are available. In the case of the rotator cuff tendinopathy, PRP resulted in better results at 3 and 6 months when compared with DN [46]. Nonetheless, a single study comparing PRP with DN in PT [21] showed better short-term results in the case of PRP but the opposite at 6 months follow up. These differences may be due to the comparison of different tendons and a different methodology, as the 


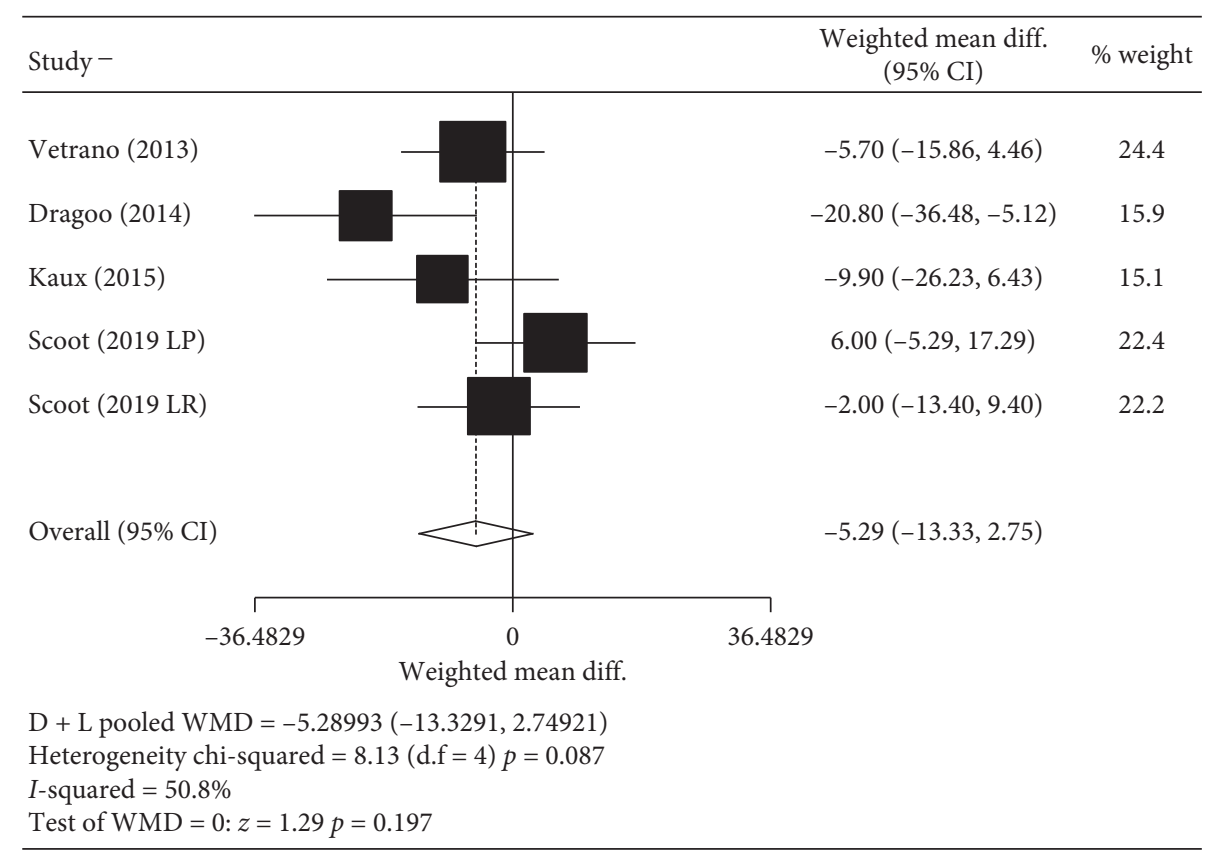

(a)

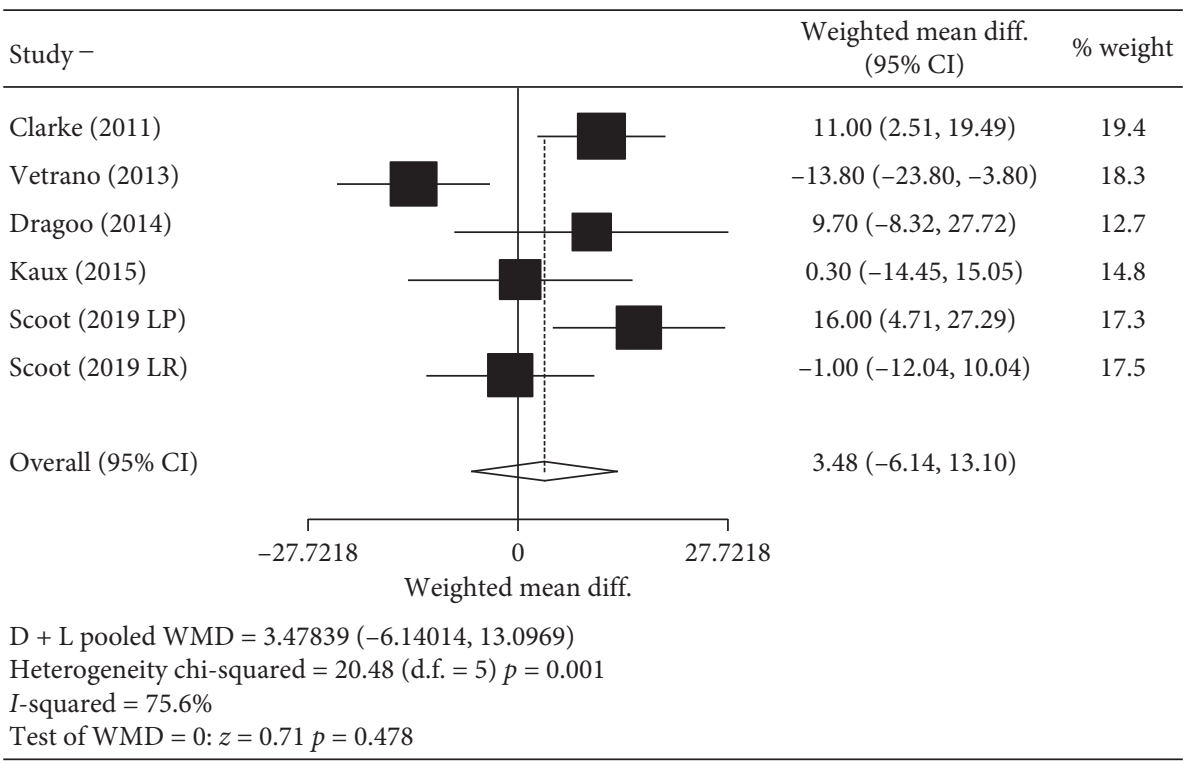

(b)

Figure 2: Analysis VISA-p mean differences. (a) Analysis VISA-p prepost mean difference. (b) Analysis of VISA-p pre-follow-up mean difference.

aforementioned studies differ in the number of injections (1-8) and dosage $(6 \mathrm{~mL}$ versus $3 \mathrm{~mL}$ of PRP and 10 versus 40-50 needle insertions for DN group) in the PT and rotator cuff tendinopathy, respectively.

In line with the study by Dragoo et al. [21] and Clarke et al. [37], in our meta-analysis according to the subgroup analysis, we can affirm that in doses of less than $4 \mathrm{~mL}$ of PRP, there is no difference between groups, and when the dose is more than $4 \mathrm{~mL}$ of PRP, in the long term, other treatments are more effective than PRP. One of such treatments is skinderived tenocyte-like cells, which has proven to be effective for the recovery of other tendinopathies, such as lateral epicondylitis [47]. Therefore, this appears to be a good option for the treatment of tendinopathies, although further studies are required to demonstrate the effectiveness of this same. According to some studies [16, 36, 45], it seems that different PRP preparations, timing, and frequency of injections should be considered in future studies as these factors could, at least in part, explain the differences in the effectiveness of this technique. A recent meta-analysis compared the application of one or two PRP injections, showing that two injections do not show better results than a single injection [16]. In our meta-analysis, we have gone further and have tried to clarify not only the number of 


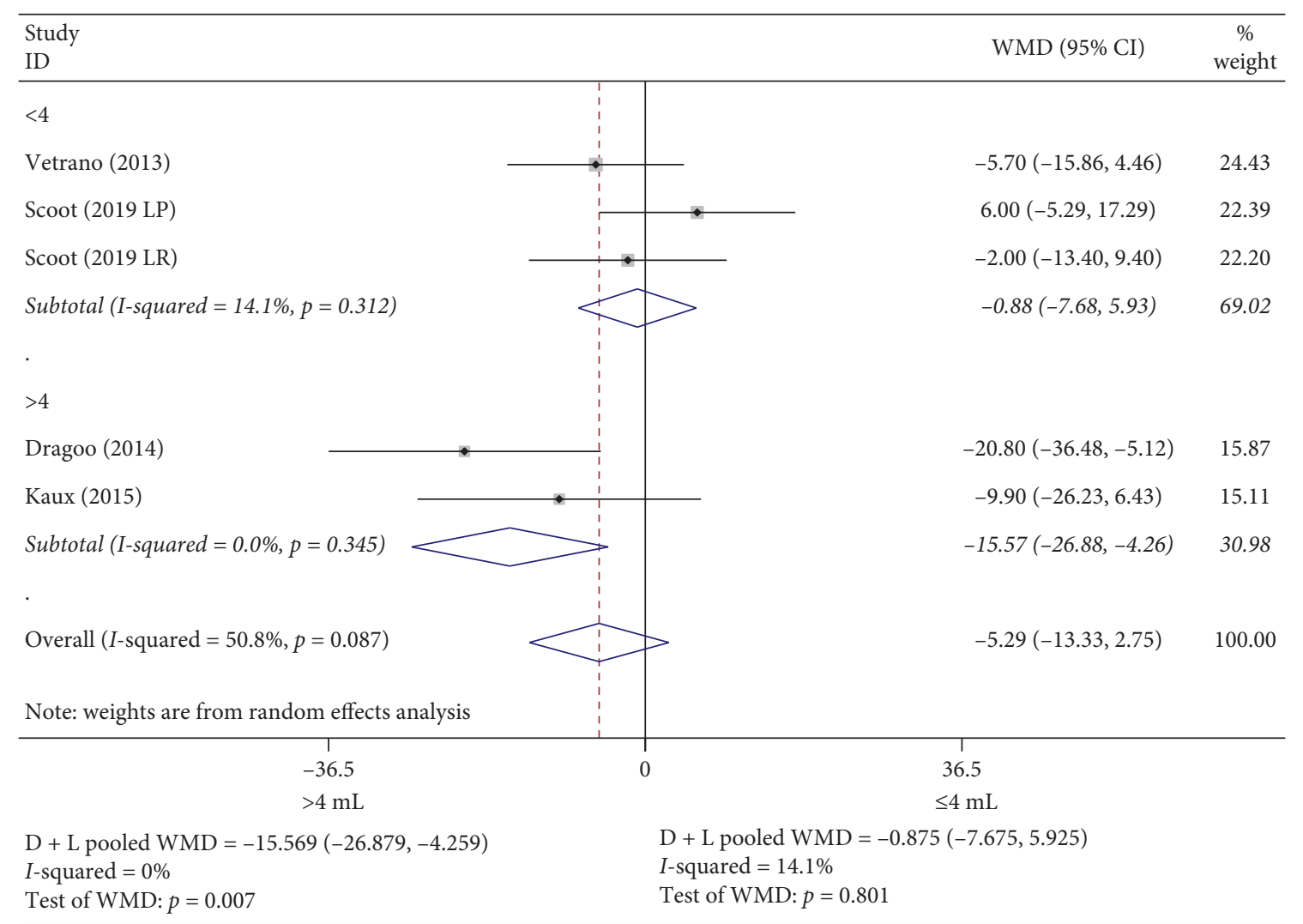

(a)

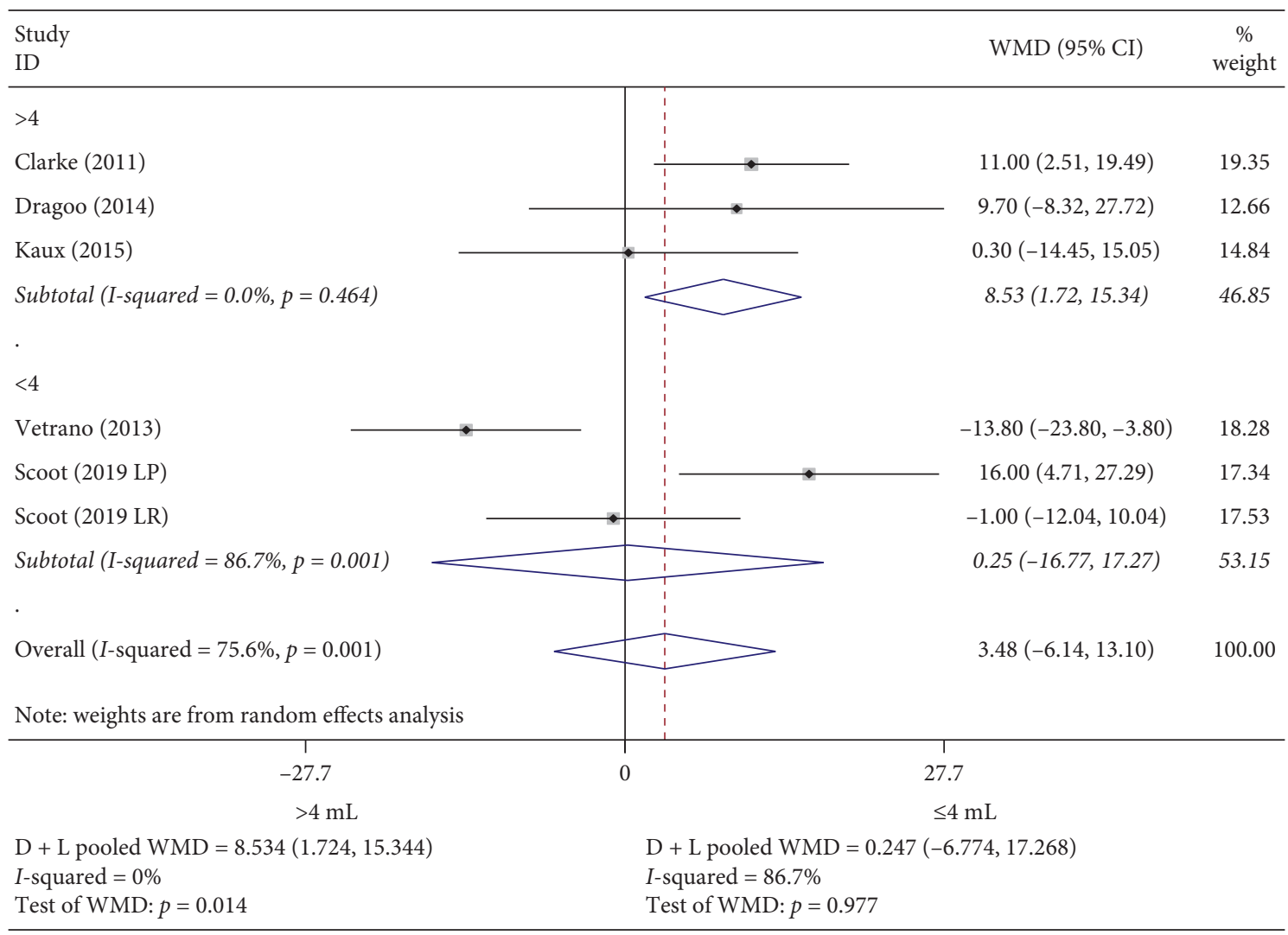

(b)

FIgURE 3: Subgroup analysis VISA-p mean difference. (a) Subgroup analysis VISA-p prepost mean difference. (b) Subgroup analysis VISA-p pre-follow-up mean difference. 


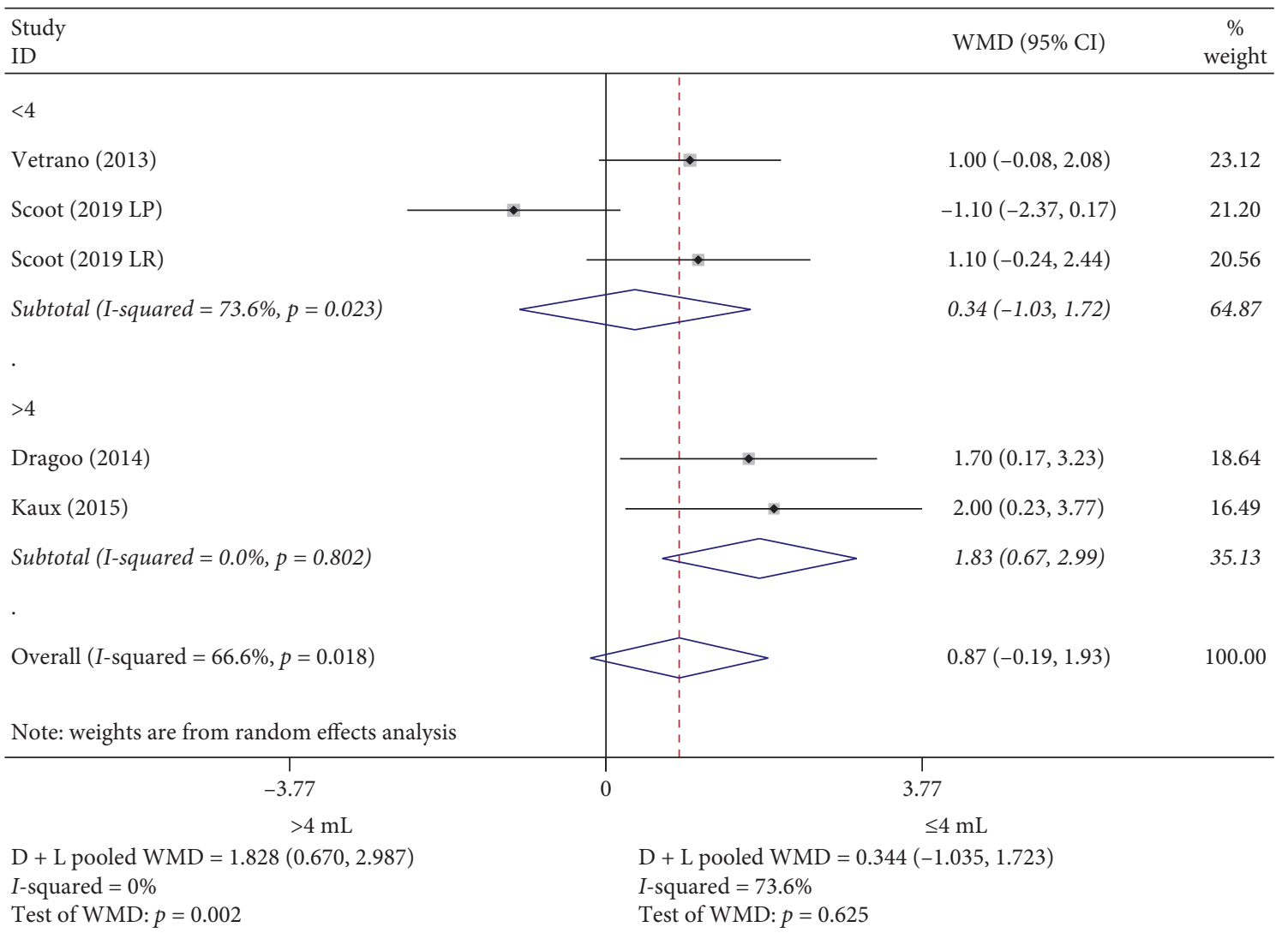

(a)

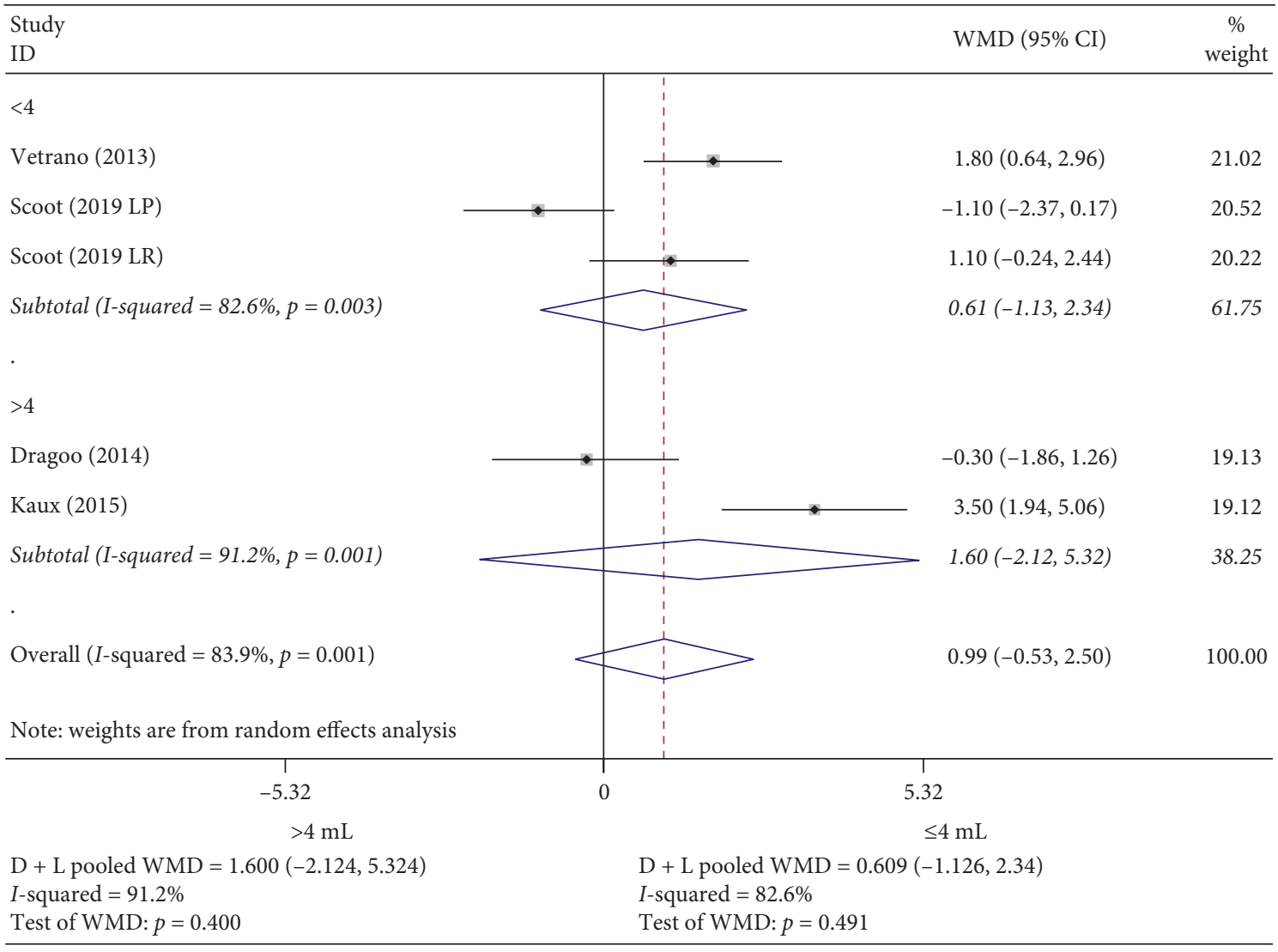

(b)

FIGURE 4: Subgroup analysis VAS mean difference. (a) Subgroup analysis VAS prepost mean difference. (b) Subgroup analysis VAS prefollow-up mean difference. 


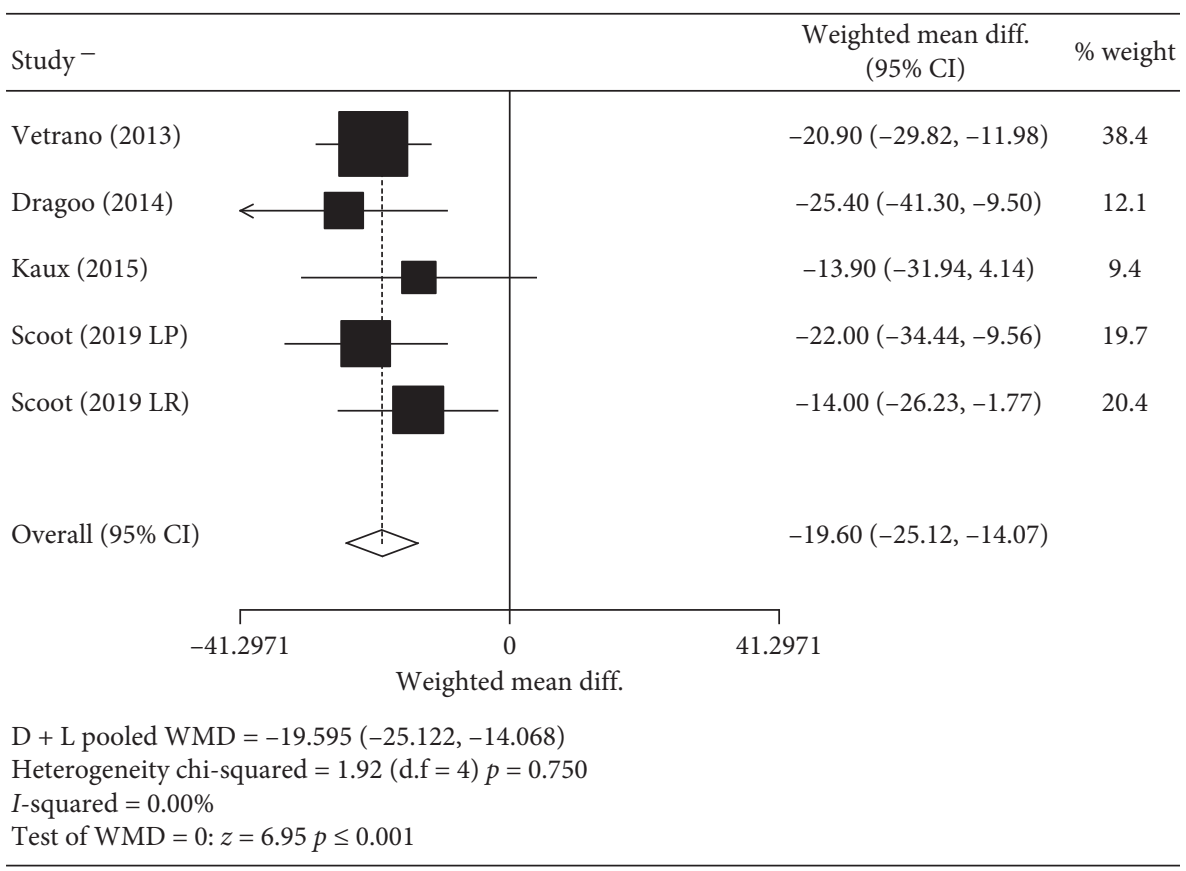

(a)

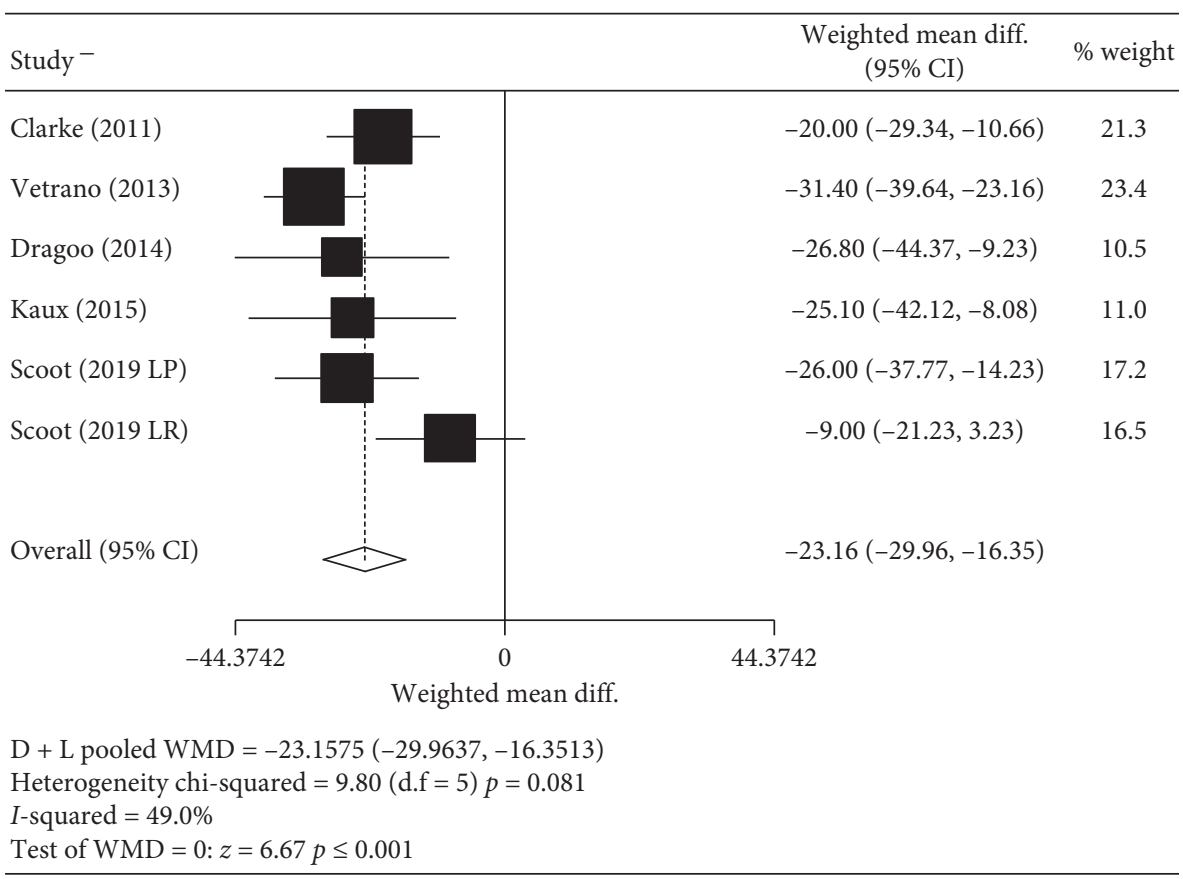

(b)

FIgURe 5: Intragroup VISA-p mean difference in the PRP group. (a) Intragroup prepost VISA-p mean difference in the PRP group. (b) Intragroup pre-follow-up VISA-p mean difference in the PRP group.

infiltrations but also what is the dose producing the vest results. Thus, our study provides novel and valuable information regarding the PRP technique and what appears to be the best dose.

In the most recent RCT (2019) [34], aimed at examining the differences between the concentration of leukocytes injected in the PRP, a platelet-rich sample was compared with a platelet-poor sample and a final control group with a saline solution. This study revealed that there are no differences between the groups neither in the short nor in the long term. Along these lines, Resteghini et al. [38] compared the effectiveness of $A B$ versus saline and found no differences between groups. Finally, this review is in line with a previous study [21] that reported that PRP was not superior to placebo or DN at a 6-month follow-up for tendinopathy treatment. These results may support the hypothesis by 


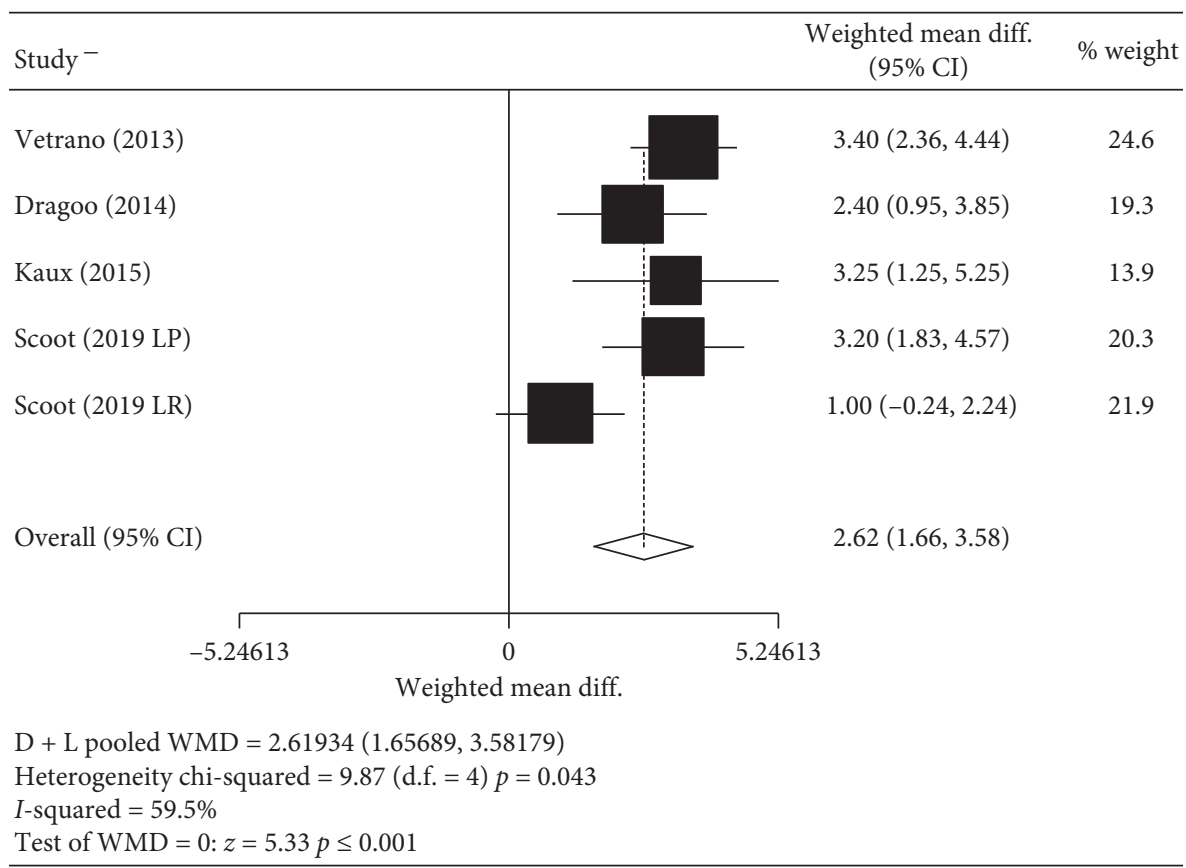

(a)

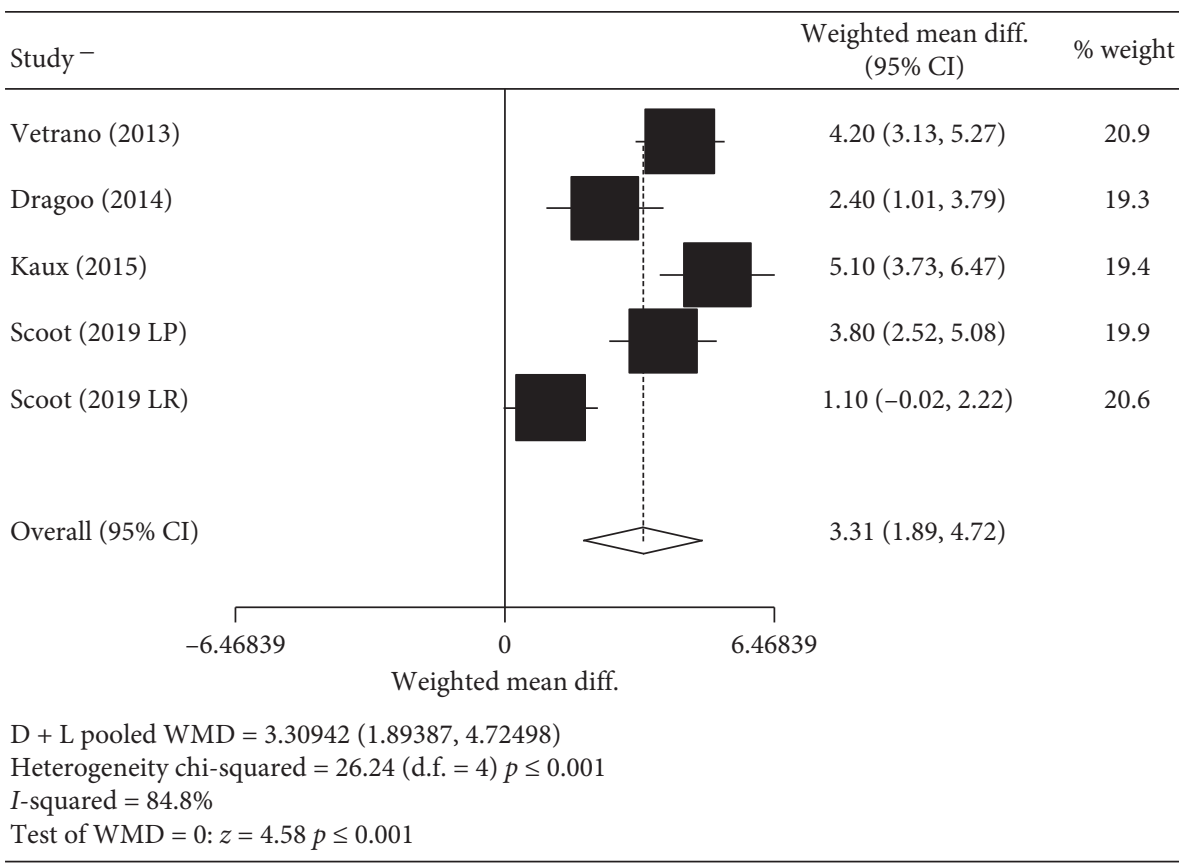

(b)

FIGURE 6: IntragroupVAS mean difference in the PRP group. (a) Intragroup prepost VAS mean difference in the PRP group. (b) Intragroup pre-follow-up VAS mean difference in the PRP group.

Vetrano [35] who proposed that needling on tissues with tendinopathy may provide cellular and humoral mediators, which promote the healing of tissues.

Although there are no RCT analyzing the effectiveness of MIT like PNE, there has been an increasing number of publications achieving excellent results in the last years $[4,18-20]$. However, it is necessary to develop RCTs analyzing not only the effect but also comparing the effectiveness between different MIT such as DN and PNE.
Fortunately, this review found two high quality protocols published that aim to compare the effects of PNE and DN in PT [41] and plantar heel pain [48], although results are not available yet.

The studies previously mentioned in this review testing cell therapy, PRP, DN, and $\mathrm{AB}[21,31,34,35,37,38]$ were accompanied by a standardized program of exercise during treatment, most of them with EE which is until now, the gold standard technique for the treatment of this injury. 
However, several studies have shown that HSR is more effective than EE [23]. Further studies are necessary to redefine the gold standard of conservative treatment of this pathology. In the subgroup analysis of functionality and pain in PRP treatment, RCTs which carried out EE programs over 6 weeks showed greater improvements than those which had a duration of less than 6 weeks. Further research is needed to elucidate the ideal type and duration of exercise programs for the different subtypes of patients with different levels of functionality.

The current systematic review and meta-analysis had several limitations due to the inherent biases of the included studies. Thus, caution should be taken when interpreting the findings. First, there is a scarcity of RCTs concerning certain MIT that do not rely on the infiltration of substances (i.e., $\mathrm{DN}$ or PNE). This hinders the possibility of performing a meta-analysis with all the MIT. Second, a standardization of treatment may be necessary (number of doses, frequency, and PRP amount). Third, publication bias may be present, as only English or Spanish language studies were included, and only 5 databases were searched; however, in order to decrease publication bias, a monthly update of the published papers on databases were performance.

\section{Conclusions}

In conclusion, the most important finding of the present study was that all studies analyzing MIT, such as PRP, DN, or cells, when combined with exercise, were found to be effective for PT at posttreatment and follow-up. Moreover, the PRP technique with doses greater than $4 \mathrm{~mL}$ together and combined with an exercise program lasting over 6 weeks obtained better results in functionality and pain compared to other treatments in the short-term. However, in the longterm, DN and skin-derived tenocyte-like cells are more effective than PRP. In addition, although the infiltration of drugs was effective at posttreatment, these improvements were not maintained over time and could have secondary effects.

\section{Abbreviations}

$\begin{array}{ll}\text { AB: } & \text { Autologous blood } \\ \text { CD: } & \text { Color Doppler sonography } \\ \text { CI: } & \text { Corticosteroid injections } \\ \text { DN: } & \text { Dry needling } \\ \text { EE: } & \text { Eccentric exercise } \\ \text { ESWT: } & \text { Extracorporeal shockwave therapy } \\ \text { HSR: } & \text { Heavy slow resistance exercises } \\ \text { LP-PRP: } & \text { Leukocyte-poor PRP } \\ \text { LR-PRP: } & \text { Leucocyte-rich PRP } \\ \text { MIT: } & \text { Minimally invasive techniques } \\ \text { MRI: } & \text { Magnetic resonance imaging } \\ \text { PNE: } & \text { Percutaneous needle electrolysis } \\ \text { PRISMA: } & \text { Preferred Reporting Items for Systematic Review } \\ & \text { and Meta-Analysis } \\ \text { PRP: } & \text { Platelet-rich plasma } \\ \text { PT: } & \text { Patellar tendinopathy } \\ \text { RCT: } & \text { Randomized controlled trial }\end{array}$

$\begin{array}{ll}\text { SD: } & \text { Standard deviation } \\ \text { VAS: } & \text { Visual analog scale } \\ \text { VISA-p: } & \text { Victorian Institute of Sport Assessment of } \\ & \text { Patellar Questionnaire } \\ \text { WOS: } & \text { Web of Science. }\end{array}$

\section{Data Availability}

The data used to support the findings of this study are included within the supplementary information file.

\section{Conflicts of Interest}

The authors declare that there are no conflicts of interest regarding the publication of this paper.

\section{Supplementary Materials}

Appendix 1: search strategy in databases. Appendix 2: methodological quality scores using the PEDro scale. (Supplementary Materials)

\section{References}

[1] B. M. Andres and G. A. C. Murrell, "Treatment of tendinopathy: what works, what does not, and what is on the horizon," Clinical Orthopaedics and Related Research, vol. 466, no. 7, pp. 1539-1554, 2008.

[2] K. Knobloch, "The role of tendon microcirculation in Achilles and patellar tendinopathy," Journal of Orthopaedic Surgery and Research, vol. 3, no. 1, 2008.

[3] N. Maffulli, J. Wong, and L. C. Almekinders, "Types and epidemiology of tendinopathy," Clinics in Sports Medicine, vol. 22, no. 4, pp. 675-692, 2003.

[4] F. D. W. Abat, P. E. Gelber, F. Polidori, J. C. Monllau, and J. M. Sanchez-Ibañez, "Effectiveness of the Intratissue Percutaneous Electrolysis $\left(\mathrm{EPI}^{\circledR}\right)$ technique and isoinertial eccentric exercise in the treatment of patellar tendinopathy at two years follow-up," Muscles Ligaments Tendons Journal, vol. 14, no. 4, pp. 188-193, 2014.

[5] M. E. H. Larsson, I. Käll, and K. Nilsson-Helander, "Treatment of patellar tendinopathy-a systematic review of randomized controlled trials," Knee Surgery, Sports Traumatology, Arthroscopy, vol. 20, no. 8, pp. 1632-1646, 2012.

[6] J. Zwerver, S. W. Bredeweg, and I. van den Akker-Scheek, "Prevalence of jumper's knee among nonelite athletes from different sports," The American Journal of Sports Medicine, vol. 39, no. 9, pp. 1984-1988, 2011.

[7] J. C. Benítez-Martínez, P. Martínez-Ramírez, F. ValeraGarrido, and F. Medina-Mirapeix, "Assessment of patellar tendinopathy in professional basketball players using algometry," Revista Fisioterapia Invasiva/Journal of Invasive Techniques in Physical Therapy, vol. 2, no. 1, pp. 2-8, 2019.

[8] A. Hoksrud, L. Oehberg, H. Alfredson, and R. Bahr, "Ultrasound-guided sclerosis of neovessels in painful chronic patellar tendinopathy: a randomized controlled trial," American Journal of Sports Medicine, vol. 39, no. 7, 2011.

[9] C. Couppé, R. B. Svensson, K. G. Silbernagel, H. Langberg, and S. P. Magnusson, "Eccentric or concentric exercises for the treatment of tendinopathies?" Journal of Orthopaedic \& Sports Physical Therapy, vol. 45, no. 11, pp. 853-863, 2015. 
[10] R. W. Willy, L. T. Hoglund, C. J. Barton et al., "Patellofemoral pain," Journal of Orthopaedic \& Sports Physical Therapy, vol. 49, no. 9, 2019.

[11] P. Malliaras, J. L. Cook, P. M. Kent, and H. Alfredson, "Anthropometric risk factors for patellar tendon injury among volleyball players * COMMENTARY," British Journal of Sports Medicine, vol. 41, no. 4, pp. 259-263, 2007.

[12] P. Pain, "Using the evidence to guide physical therapist practice," Journal of Orthopaedic \& Sports Physical Therapy, vol. 49, no. 9, pp. 631-632, 2019.

[13] H. Y. Lim and S. H. Wong, "Effects of isometric, eccentric, or heavy slow resistance exercises on pain and function in individuals with patellar tendinopathy: a systematic review," Physiotherapy Research International, vol. 23, no. 4, Article ID e1721, 2018.

[14] J. S. Everhart, D. Cole, J. H. Sojka et al., "Treatment options for patellar tendinopathy: a systematic review," Arthroscopy: The Journal of Arthroscopic \& Related Surgery, vol. 33, no. 4, pp. 861-872, 2017.

[15] L. Dupley and C. P. Charalambous, "Platelet-rich plasma injections as a treatment for refractory patellar tendinosis: a meta-analysis of randomised trials," Knee Surgery \& Related Research, vol. 29, no. 3, pp. 165-171, 2017.

[16] L. Andriolo, S. A. Altamura, D. Reale, C. Candrian, S. Zaffagnini, and G. Filardo, "Nonsurgical treatments of patellar tendinopathy: multiple injections of platelet-rich plasma are a suitable option: a systematic review and metaanalysis," The American Journal of Sports Medicine, vol. 47, no. 4, pp. 1001-1018, 2019.

[17] S. L. J. James, K. Ali, C. Pocock et al., "Ultrasound guided dry needling and autologous blood injection for patellar tendinosis * COMMENTARY," British Journal of Sports Medicine, vol. 41, no. 8, pp. 518-521, 2007.

[18] F. Abat, P. E. Gelber, F. Polidori, J. C. Monllau, and J. M. Sanchez-Ibañez, "Clinical results after ultrasoundguided intratissue percutaneous electrolysis (EPI) and eccentric exercise in the treatment of patellar tendinopathy," Knee Surgery, Sports Traumatology, Arthroscopy, vol. 23, no. 4, pp. 1046-1052, 2015.

[19] B. D. Torres, M. A. Cabello, P. G. Bermejo, and J. N. Orellana, "Autonomic responses to ultrasound-guided percutaneous needle electrolysis of the patellar tendon in healthy male footballers," Acupuncture in Medicine, vol. 34, no. 4, pp. 275-279, 2016.

[20] F. Valera Garrido, F. Minaya Muñoz, and S. I. JM, "Effectiveness of electrolysis percutaneous intratisular $\left(\mathrm{EPI}{ }^{\circledR}\right)$ in chronic insertional patellar tendinopathy," Trauma Fund MAPFRE, vol. 21, no. 4, pp. 227-236, 2010.

[21] J. L. Dragoo, A. S. Wasterlain, H. J. Braun, and K. T. Nead, "Platelet-rich plasma as a treatment for patellar tendinopathy," The American Journal of Sports Medicine, vol. 42, no. 3, pp. 610-618, 2014.

[22] H. K. Alfredson and L. Ohberg, "Neovascularisation in chronic painful patellar tendinosis? promising results after sclerosing neovessels outside the tendon challenge the need for surgery," Knee Surgery, Sports Traumatology, Arthroscopy, vol. 13, no. 2, pp. 74-80, 2005.

[23] M. Kongsgaard, V. Kovanen, P. Aagaard et al., "Corticosteroid injections, eccentric decline squat training and heavy slow resistance training in patellar tendinopathy," Scandinavian Journal of Medicine \& Science in Sports, vol. 19, no. 6, pp. 790-802, 2009.

[24] K. Tsikopoulos, I. Tsikopoulos, E. Simeonidis et al., "The clinical impact of platelet-rich plasma on tendinopathy compared to placebo or dry needling injections: a metaanalysis," Physical Therapy in Sport, vol. 17, pp. 87-94, 2016.

[25] A. D. Liddle and E. C. Rodríguez-Merchán, "Platelet-rich plasma in the treatment of patellar tendinopathy," The American Journal of Sports Medicine, vol. 43, no. 10, pp. 2583-2590, 2015.

[26] D. U. Jeong, C. R. Lee, J. H. Lee et al., "Clinical applications of platelet-rich plasma in patellar tendinopathy," BioMed Research International, vol. 2014, Article ID 249498, , 2014.

[27] D. Figueroa, F. Figueroa, and R. Calvo, "Patellar tendinopathy," Journal of the American Academy of Orthopaedic Surgeons, vol. 24, no. 12, pp. e184-e192, 2016.

[28] L. M. Mendonca, H. R. Leite, J. Zwerver, N. Henschke, G. Branco, and V. C. Oliveira, "How strong is the evidence that conservative treatment reduces pain and improves function in individuals with patellar tendinopathy? A systematic review of randomised controlled trials including GRADE recommendations," British Journal of Sports Medicine, vol. 54, no. 2, p. 87, Article ID 93, 2019.

[29] V. Welch, M. Petticrew, P. Tugwell et al., "PRISMA-equity 2012 extension: reporting guidelines for systematic reviews with a focus on health equity," Revista Panamericana De Salud Publica-Pan American Journal of Public Health, vol. 34, no. 1, pp. 60-67, 2013.

[30] S. Hernandez-Sanchez, M. D. Hidalgo, and A. Gomez, "Crosscultural adaptation of VISA-P score for patellar tendinopathy in Spanish population," Journal of Orthopaedic \& Sports Physical Therapy, vol. 41, no. 8, pp. 581-591, 2011.

[31] R. Zayni, M. Thaunat, J. M. Fayard et al., "Platelet-rich plasma as a treatment for chronic patellar tendinopathy: comparison of a single versus two consecutive injections," Muscles Ligaments Tendons Journal, vol. 3, no. 5, pp. 92-98, 2015.

[32] J. P. T. Higgins and S. G. Thompson, "Quantifying heterogeneity in a meta-analysis," Statistics in Medicine, vol. 21, no. 11, pp. 1539-1558, 2002.

[33] J. P. T. Higgins, S. G. Thompson, J. J. Deeks, and D. G. Altman, "Measuring inconsistency in meta-analyses," Bmj, vol. 327, no. 7414, pp. 557-560, 2003.

[34] A. Scott, R. F. LaPrade, K. G. Harmon et al., "Platelet-rich plasma for patellar tendinopathy: a randomized controlled trial of leukocyte-rich PRP or leukocyte-poor PRP versus saline," The American Journal of Sports Medicine, vol. 47, no. 7, pp. 1654-1661, 2019.

[35] M. Vetrano, A. Castorina, M. C. Vulpiani, R. Baldini, A. Pavan, and A. Ferretti, "Platelet-rich plasma versus focused Shock waves in the treatment of jumper's knee in athletes," The American Journal of Sports Medicine, vol. 41, no. 4, pp. 795-803, 2013.

[36] J. F. Kaux, J. L. Croisier, B. Forthomme et al., "Using plateletrich plasma to treat jumper's knees: exploring the effect of a second closely-timed infiltration," Journal of Science and Medicine in Sport, vol. 19, no. 3, pp. 200-204, 2016.

[37] A. W. Clarke, F. Alyas, T. Morris, C. J. Robertson, J. Bell, and D. A. Connell, "Skin-derived tenocyte-like cells for the treatment of patellar tendinopathy," The American Journal of Sports Medicine, vol. 39, no. 3, pp. 614-623, 2011.

[38] P. Resteghini, T. A. Khanbhai, S. Mughal, and Z. Sivardeen, "Double-Blind randomized controlled trial," Clinical Journal of Sport Medicine, vol. 26, no. 1, pp. 17-23, 2016.

[39] U. Fredberg, L. Bolvig, M. Pfeiffer Jensen, D. Clemmensen, B. Jakobsen, and K. Stengaard Pedersen, "Ultrasonography as a tool for diagnosis, guidance of local steroid injection and, together with pressure algometry, monitoring of the treatment of athletes with chronic jumper's knee and Achilles 
tendinitis: a randomized, double-blind, placebo-controlled study," Scandinavian Journal of Rheumatology, vol. 33, no. 2, pp. 94-101, 2004.

[40] L. Willberg, K. Sunding, M. Forssblad, M. Fahlstrom, and H. Alfredson, "Sclerosing polidocanol injections or arthroscopic shaving to treat patellar tendinopathy/jumper's knee? a randomised controlled study," British Journal of Sports Medicine, vol. 45, no. 5, pp. 411-415, 2011.

[41] M. P. Lopez-Royo, E. M. Gomez-Trullen, M. Ortiz-Lucas et al., "Comparative study of treatment interventions for patellar tendinopathy: a protocol for a randomised controlled trial," BMJ Open, vol. 10, no. 2, Article ID e34304, 2020.

[42] B. K. Coombes, L. Bisset, and B. Vicenzino, "Efficacy and safety of corticosteroid injections and other injections for management of tendinopathy: a systematic review of randomised controlled trials," The Lancet, vol. 376, no. 9754, pp. 1751-1767, 2010.

[43] M. van Ark, J. Zwerver, and I. van den Akker-Scheek, "Injection treatments for patellar tendinopathy," British Journal of Sports Medicine, vol. 45, no. 13, pp. 1068-1076, 2011.

[44] S.-K. Chen, C.-C. Lu, P.-H. Chou, L.-Y. Guo, and W.-L. Wu, "Patellar tendon ruptures in weight lifters after local steroid injections," Archives of Orthopaedic and Trauma Surgery, vol. 129, no. 3, pp. 369-372, 2009.

[45] U. Balasubramaniam, R. Dissanayake, and L. Annabell, "Efficacy of platelet-rich plasma injections in pain associated with chronic tendinopathy: a systematic review," The Physician and Sportsmedicine, vol. 43, no. 3, pp. 253-261, 2015.

[46] D.-w. Rha, G.-Y. Park, Y.-K. Kim, M. T. Kim, and S. C. Lee, "Comparison of the therapeutic effects of ultrasound-guided platelet-rich plasma injection and dry needling in rotator cuff disease: a randomized controlled trial," Clinical Rehabilitation, vol. 27, no. 2, pp. 113-122, 2013.

[47] D. Connell, A. Datir, F. Alyas, and M. Curtis, "Treatment of lateral epicondylitis using skin-derived tenocyte-like cells," British Journal of Sports Medicine, vol. 43, no. 4, pp. 293-298, 2009.

[48] Z. Al-Boloushi, E. M. Gómez-Trullén, P. Bellosta-López, M. P. López-Royo, D. Fernández, and P. Herrero, "Comparing two dry needling interventions for plantar heel pain: a protocol for a randomized controlled trial," Journal of Orthopaedic Surgery and Research, vol. 14, no. 1, p. 31, 2019. 